\title{
Editorial
}

\section{A decade of sustainability debates}

\author{
By: Gabriela Litre, Melissa Curi, Marcel Bursztyn, Carlos Saito
}

doi:10.18472/SustDeb.v10n3.2019.28649

The Editorial Team of the Journal Sustainability in Debate celebrates, along with its readers, authors, revisors and members of the Editorial Board, its first 10 years of existence.

Thanks to an interdisciplinary profile and a wide-opened vision to avant-garde issues, researchers from diverse areas have published more than 400 articles, debates, interviews, galleries (photo essays) and reviews in these first 27 editions. Besides, 11 thematic dossiers and a special number have also contributed to reach nearly 900 citations in Google Scholar. This result is also due to SeD's integration by prestigious indexing platforms, such as Scopus which is the one that concentrates the largest number of scientific articles worldwide and through which the geographic representativity of our authors has been expanded.

Among this first decade's many achievements, SeD has also strengthened, in 2019, an internationalization process financed by FAPDF (Fundação de Apoio à Pesquisa do Distrito Federal) that includes the translation into English of all documents accepted for publication. This simple method had a significative impact on Google Scholar and Google Analytics indicators. This effect confirms a clear increase in our journal's international visibility, with nearly half a million of visits on the website coming from individual IPs from 133 different countries. Thus, the number of downloads from abroad per article and of English, Spanish or French written manuscripts' submission has also increased.

When SeD started its quarterly publication in 2016, the journal also accelerated its peer-review and dissemination process. Nonetheless, the quality and scientific rigor of evaluation did not suffer from these changes. SeD's performance also played a key role in the qualification as an excellence program of the Post Graduate Program in Sustainable Development from the University of Brasilia (CDS-UNB), being given by CAPES the highest grade (7) in the Environmental Sciences area. CDS-UNB edits the journal along with the Brazilian Institute of Sustainability (IABS). Currently, evaluated as a B1 by the Qualis system from CAPES, in the Environmental Sciences Area, $\mathrm{SeD}$ has acquired the necessary elements for being reconsidered as a scientific journal of A level.

Alongside the choice of publishing entirely in English, the journal has also focused on the renewal of the Editorial Board and on the creation of a Scientific Board to increase its geographic, disciplinary and institutional representativity. These efforts increase the impact and accessibility of SeD's contain on an international level. The journal's team hopes that with such initiatives it will be easier to boost its position in the Environmental Sciences and Public Policy areas, not without continuously keeping its interdisciplinary focus.

These actions, motivated by the goal of spreading good practices, knowledge and data production about sustainability, have strengthened more and more the role of jour journal as a platform of knowledge meetings that allows a coherent and sustainable interaction, in line with global strategies, with the Sustainable Development Goals and with the Paris Agreement on Climate Change, both under the auspices of the UN. 
Over the course of these 10 years we always mentioned, in our Editorials, the major issues that marked the period between each edition. We attempt to maintain a clear position in favor of sustainability and redeem a constructive point of view of the issue at hand. Among our discussed topics, on a national level we have brought, for example, the environmental legislation regression, the challenges resulting from the 2016 Olympics in Rio, the socioenvironmental impacts linked to climate change, such as desertification that puts at risk communities with traditional ways of life in the semiarid from the Northeast region. Internationally, the editorials addressed the RIO+20 Conference heritage, the withdrawal of the United States from the Paris Agreement, the water scarcity, the planetary boundaries and the gender issue in the sustainability debate

We also brought to light challenging questions for sustainability promotion that have been under discussion in 11 dossiers and a special number (the Harmonious Living in the Semi-arid paradigm, in 2016). Some of the themes that we elaborated in collaboration with renowned specialists from different universities and research centers from Brazil and abroad were: Climate Change and Land use; Gender and Water Resources; Public Policy and Territorial Development; Socio-ecological Resilience at the Amazonian Border; Eco-systemic Approaches in Health; Environment and Sustainability and this edition's dossier: Management of Water and Protected Areas. Besides, for the August edition of 2020, we prepare a dossier on Environmental System Modeling and Landscape Management, in collaboration with the Federal University of Minas Gerais.

Aside from publishing vanguard articles, Sed also presents unique and original sections that stimulate the debate and alternative perspectives on sustainability. Therefore, the journal's team had the honor to interview and debate with remarkable figures from the national and international sphere, such as former Environment Minister, Marina Silva, Joan Martinez-Alier, Ignacy Sachs, Vandana Shiva, José Eli da Veiga, Oran R. Young, Roldan Muradian, Esteve Cordera, Tânia Bacelar, Carlos Nobre, Cristovam Buarque, Lance Gunderson, Catherine Aubertin, Anthony Hall, Pedro Jacobi, Leila da Costa Ferreira and José Augusto de Padua.

Our Galleries have also been innovative. These art and photo shoots that always combined artistic quality with scientific accuracy have, during many years, closed our editions, bringing forward the richness of the debate between different areas of knowledge and point of views. In addition to the main function of illustration, the Gallery section brought, in a vivid way, the socio-environmental diversity, stimulating our readers on sustainability discusions.

Looking ahead, the challenges are inspiring. Our main principle will always be to guarantee free access to everything we publish (open access) and we will continue to adopt the double-blind peer-review process. The indexation procedures on Web of Science and SciELO being initiated, we hope that in the near future we will be part of these two platforms which will increase our impact factor. Moreover, the SciELO platform includes continuous publication of accepted manuscripts. Another project of ours is the creation of social media profiles on Twitter, Linkedln and Instagram, besides of its Facebook page that already exists. Furthermore, sometimes very soon, we pretend to develop a specific page of our journal on Wikipedia.

In the context of the $25^{\text {th }}$ Climate Change Conference in Madrid, SeD continues to promote scientific debates of quality, especially in an era marked by important environmental setbacks, nationally and internationally, Among those, we cannot ignore the withdrawal of the United States from the Paris Agreement, considering the fact that the American society generates, per head of population, 3,5 times more pollution caused by $\mathrm{CO} 2$ than the global average ${ }^{1}$.

Nonetheless, among American citizens the acknowledgement of this global crises linked to climate change is increasing. Besides, some feel that their president have not done the necessary effort in

\footnotetext{
${ }^{1}$ Jackson, R.; Canadell, P. What's 'Fair' When It Comes to Carbon Emissions?. Published in The New York Times, on the 4th of December, 2019. Available at: https://www.nytimes.com/2019/12/04/opinion/global-climate-change.html
} 
order to tackle this issue, as we can see it from a survey conducted by The Washington Post and the Kaiser Family Foundation, results of which have been divulgated on the 13th of September, 2019. A mark point research in this area is the World Scientists' Warning of a Climate Emergency, published by the Bioscence Journal in November of $2019^{2}$. This article, coordinated by William J. Ripple and Christopher Wolf from the Oregon State University, received support signatures from 11258 scientists from 153 countries.

The strenuous battle in favor of sustainability expressed worldwide is mirrored in SeD's publications, as part of its compromise to amplify this debate.

In the present edition, Sustainability in Debate nourishes its pursuit of excellence through a Dossier with eleven articles, intitled "Management of Water and Protected Areas", as well as three articles varia and a book review.

In section Varia, "Deforestation and the ideologies of the frontier expansion: the case of criticism of the Brazilian amazon monitoring program", produced by Roberto Araújo and Ima Vieira, presents some elements that allow to contextualize recent attacks to the Brazilian Amazon Monitoring Project carried out by the Brazilian government on deforestation rates.

In the article "International climate change negotiation: the role of Brazil", the authors Marcela Cardoso Guilles da Conceição et al. systemize information about how international negotiations on climate have been organized and they also analyze the role Brazil developed during these negotiations and the future perspectives for the country.

"Socioenvironmental networks and international cooperation: the Global Alliance for Recycling and Sustainable Development- GARSD" is the third article that constitutes the section Varia. Luciana Ziglio and Wagner Ribeiro introduce the concept of international cooperation and present the socioenvironmental network Global Alliance for Recycling and Sustainable Development - GARSD.

The Book Review section presents Mireya Perafán's work of "Landscape of Freedom - Building a Postemancipation Society in the Rainforests of Western Colombia".

To closure this commemorative editorial, we wish to express our gratitude to all those that helped us during this journey: the editorial and design team, the authors and reviewers. We also want to acknowledge the institutions that support us financially: the IPEA and the FAPDF. Finally, we thank IABS's partners for their efficiency and work of quality and to the teams of the Central Library of the University of Brasilia (BCE) for assisting us with editorial challenges from the beginning and help our journal to continue in the SEER system from the BCE.

We wish you all a very happy holiday season and a Happy New Year.

The Editors

\footnotetext{
${ }^{2}$ (https://www.washingtonpost.com/climate-environment/americans-increasingly-see-climate-change-as-a-crisis-poll-shows/2019/09/12/ 74234db0-cd2a-11e9-87fa-8501a456c003_story.html).
} 